\title{
NO-REFERENCE QUANTITATIVE ASSESSMENT OF GENERALIZED CONTRAST FOR COMPLEX IMAGES
}

Context. Nowadays the task of automatically measuring of image quality in real time is extremely relevant for the vast majority of practical applications. No-reference quantitative assessment of image quality is one of the most pressing and difficult problems of image processing. Generalized contrast is the most important quantitative characteristic which determines the objective quality of the image. Currently, the development of new effective methods of no-reference measuring of generalized contrast for complex image in automatic mode which have the level of computing costs, which are acceptable to implement the processing in real time, is one of the most urgent tasks of image pre-processing.

Objective. Development of new histogram-based method for no-reference measurement of generalized contrast of complex images on the basis of the mean value for all contrast values of all pairs of image elements (objects and background) for various definitions of contrast kernel.

Method. Analysis of known approaches to measurement of a local contrast of the image elements, of known methods of the quantitative assessment of generalized contrast of complex images as well of the results of experimental research for a series of complex real and test images allowed to reveal inherent patterns (accordance to basic requirements to the definition of contrast, the nature and the dynamic of contrast changes at the linear transformations of the brightness scale), which are manifested depending on the use of the different definitions of the contrast kernels and the metrics of generalized contrast of images.

Results. New histogram-based method for no-reference measurement of generalized contrast for complex images is proposed. Noreference contrast metrics for the histogram-based measuring of generalized contrast of complex images on the basis of the average contrast of image elements for different definitions of contrast kernel is proposed.

Conclusions. Proposed no-reference metrics on the basis of the average contrast of image elements for proposed contrast kernels allow providing accurate quantitative assessment of generalized contrast of the real complex images and enable to evaluate (predict) with reasonable accuracy the perceived image quality at carrying out of subjective (qualitative) expert estimates.

Keywords: image processing, image quality assessment, contrast measurement, no reference metric, generalized contrast, complex image, histogram.

\section{NOMENCLATURE}

$C\left(L_{1}, L_{2}\right)$ is a contrast for two contiguous image elements; $C_{a v e}$ is an averaged value of contrast of current image;

$C_{\text {gen }}^{\text {ave }}$ is a value of the generalized contrast of current image;

$C^{N}\left(L_{1}, L_{2}\right)$ is a weighted contrast of Nesteruk for two image elements;

$C^{\text {wei }}\left(L_{1}, L_{2}\right)$ is a weighted contrast of image elements;

$C^{r e l_{1}}\left(L_{1}, L_{2}\right)$ is a relative contrast of image elements;

$C^{r e l_{2}}\left(L_{1}, L_{2}\right)$ is a relative contrast of image elements;

$C^{V r b}\left(L_{1}, L_{2}\right)$ is an absolute contrast of Vorobel for two image elements;

$C^{V B}\left(L_{1}, L_{2}\right)$ is an absolute contrast of Vorobel and Berehulyak for two image elements;

$C^{Y}\left(L_{1}, L_{2}\right)$ is a linear contrast of image elements;

$C_{\text {gen }}^{N}\left(L_{0}\right)$ is a generalized contrast for contrast kernel of Nesteruk for adaptation level $L_{0}$;

$C_{\text {gen }}^{\text {wei }}\left(L_{0}\right)$ is a generalized contrast for weighted contrast kernel for adaptation level $L_{0}$;

$C_{\text {gen }}^{V}\left(L_{0}\right)$ is a generalized contrast for contrast kernel of Vorobel for adaptation level $L_{0}$;

$C_{\text {gen }}^{V B}\left(L_{0}\right)$ is a generalized contrast for contrast kernel of

Vorobel and Berehulyak;
$C_{a v e}^{N}$ is an averaged contrast for weighted contrast kernel of Nesteruk;

$C_{\text {ave }}^{\text {wei }}$ is an averaged contrast for weighted contrast kernel;

$C_{a v e}^{V}$ is an averaged contrast for absolute contrast kernel of Vorobel;

$C_{\text {ave }}^{V B}$ is an averaged contrast for absolute contrast kernel of Vorobel and Berehulyak;

$C_{\text {ave }}^{Y}$ is an averaged contrast for linear contrast kernel;

$f(C, p(L))$ is a function of averaging of contrast values of image elements;

$g(C, r(C))$ is a function of generalized contrasts of image elements;

$L(S)$ is a function of brightness values of pixels of image $X$;

$L$ is an average value of brightness $L$ of image pixels;

$L_{0}$ is a value of the adaptation level for current image;

$L_{i}$ is a value of brightness of $i$-th element of image $X$;

$L_{\min }$ is a minimum brightness values of elements of initial image $X$;

$L_{\max }$ is a maximum brightness values of elements of initial image $X$;

$L \mathrm{MAX}$ is a maximum possible value of brightness $L$;

$p\left(L_{i}\right)$ is a density distribution function of values of brightness $L$; 
$p\left(L_{i}, L_{j}\right)$ two-dimensional probability density function of values of brightness $L$;

$r(C)$ is a density distribution of values of contrast of image elements;

$S$ is a closed set of pixels of initial image $X$;

$S_{i}$ is a nonempty connected $i$-th subsets of pixels of initial image $X$;

$X(S, L)$ is the initial image.

\section{INTRODUCTION}

Currently, the development of new effective techniques of image quality assessment is one of the most urgent and important tasks in imaging, pre-processing and analysis of images $[1,2]$.

The object of study is the process of contrast measurement for image quality assessment.

The image quality usually defined on the basis of main objective characteristics (parameters) of current image [3, 4]. The main characteristic which defines the objective quality of image is its generalized contrast $[3,5]$. At present, however, quantitative assessment and measurement of values of generalized contrast for complex images are not defined uniquely in the literature.

The generalized contrast of complex images is usually defined basing on the values of quantitative assessments of contrast for all individual pairs of image elements (objects and background) $[6,7]$. Contrast of two image elements (of two objects or an object and the background) is a dimensionless function, which characterizes the difference between the values of their brightness [7].

The choice of contrast definition of image elements (of contrast kernel) is very important problem and appreciably defines the effectiveness (the accuracy) of measurement of the generalized contrast of complex (multi-element) images [8]. Definitions of the contrast of image elements shall meet the basic requirements to the contrast definition [8] and should ensure reasonably accurate quantitative assessment (measurement) of contrast of image elements for the real complex images and should allow evaluate (predict) the perceived values of image contrast at carrying out of subjective (qualitative) expert assessments [4].

The various definitions of contrast of image elements are known [8]. However, the known definitions of contrast have several very significant disadvantages $[8,9]$. The main disadvantages of the most of the known definitions of contrast are the uncertainty and the multiplicity of the conditions under which the extreme values of contrast are achieved. Also, the essential disadvantage of known contrast of contrast is great changes (non-invariance) of their values under linear transformations of the brightness scale of image.

Currently, the development of new efficient contrast metrics for the accurate quantitative assessment (of measurement) of the objective quality of images is an extremely urgent task in imaging, image processing and analysis. For elimination of these disadvantages the metric of generalized contrast of image on the basis of the averaged contrast for all pairs of image elements (objects and background) with the using various definitions of contrast kernels is proposed. This will also improve the accuracy of measurements of the generalized contrast of multi-element images with a complex structure. Histogram-based method for no-reference measuring of generalized contrast of complex images is also proposed.

The subject of study is the histogram-based methods of no-reference contrast measurement for complex images.

The purpose of the work is to increase the accuracy of formation of quantitative assessments (of measurement) of contrast of multi-element images with complex structure by development of new metrics of the generalized contrast.

\section{PROBLEM STATEMENT}

Let's suppose that given the initial image $X=\{X(S, L)\}$, where $L$ is a function of brightness which is defined on the closed set $S$ of image pixels, where $L: S \rightarrow[0,1] \subset R$.

We suppose there is a partition $S=\left\{S_{1}, S_{2}, \ldots, S_{k}\right\}$ of the closed set $S$ of pixels of image $X$ on $k(k \geq 2)$ the nonempty connected subsets (regions) $S_{i}, i=\overline{1, k}$ which correspond to the image elements (to the objects and the background), and $S_{i} \subset S, \quad \bigcup_{i=1}^{k} S_{i}=S, \quad S_{i} \cap S_{j}=\varnothing$ $\forall i \neq j, \quad i, j \in[1, k], \quad k \in N \wedge k \geq 2, \quad L_{i}=L\left(z \mid z \in S_{i}\right)$, $L: S_{i} \rightarrow L_{i} \in[0,1] \subset R, i=\overline{1, k}$.

Also the probability density $p(L)$ of brightness $L$ of image $X$ is known,

where $p\left(L_{i}\right)=\left|S_{i}\right| /|S|=\left|S_{i}\right| / \sum_{j=1}^{k}\left|S_{j}\right|, L_{i} \in[0,1], 1 \leq i \leq k$.

Suppose given the definition of the contrast $C(\cdot, \cdot)$ of two contiguous image elements, $C: L \times L \rightarrow[-1,1] \subset R$, which is the asymmetric dimensionless function and satisfies the main requirements to contrast definition, namely: $C\left(L_{i}, L_{j}\right)=-C\left(L_{j}, L_{i}\right), \quad C\left(L_{i}, L_{j}\right)=0 \quad$ only when $L_{i}=L_{j}, \quad\left|C\left(L_{i}, L_{j}\right)\right|=\max _{(n, m)}\left|C\left(L_{n}, L_{m}\right)\right|$ only when $\left|L_{i}-L_{j}\right|=\max _{(n, m)}\left|L_{n}-L_{m}\right|$.

The purpose of the work is the measurement of generalized contrast of multi-element images with complex structure. The generalized contrast $C_{g e n}$ is defined as average value of contrasts $C(\cdot, \cdot)$ at the boundaries of the objects and background, where $r(\cdot)$ is density distribution of contrast $C(\cdot, \cdot)$

$$
C_{\text {gen }}=g(C, r(C))=\int_{-\infty}^{\infty}\left|C\left(L_{i}, L_{j}\right)\right| \cdot r\left(C\left(L_{i}, L_{j}\right)\right) d C\left(L_{i}, L_{j}\right),
$$

where $g:(C, r(C)) \rightarrow[0,1]$.

However, the edges detection and the assessment of distribution $r(\cdot)$ of contrast values $C(\cdot, \cdot)$ on the boundaries of objects and background are very challenging.

For a given definition of $C(\cdot, \cdot)$ and the known values $\left.\left\{p\left(L_{i}\right)\right\}\right|_{i=\overline{1, k}}$ the problem of measuring the generalized contrast $C_{\text {gen }}$ can be presented as the problem of measurement 
of the mean of the all values of contrast for all pairs of elements on current image, $C_{g e n}=f(C, p(L))$. In turn, the problem of measurement of the mean of the all values of contrast for all pairs of image elements is to find such function $f:(C,\{p(L)\}) \rightarrow[0,1] \subset R$, which satisfy to all main requirements to the definition of contrast and is invariant under the linear transformations of the brightness scale of the image.

\section{REVIEW OF THE LITERATURE}

The unambiguous and generally accepted definition of the generalized contrast for complex images is currently unknown. The contrast measurement for complex images is usually carried out by analyzing of contrast values of image elements. Contrast of image elements is usually defined as the difference of brightness values on the boundary of the two image elements (of two objects or object and background). Currently, the various definitions of the contrast of pairs of image elements for various applications are known [8]. In [6] Nesteruk (1970) proposed a definition of the weighted contrast for two elements of a complex image for adaptation level $L_{0}$ :

$$
C^{N}\left(L_{1}, L_{2}\right)=\left(L_{1} \cdot L_{2}-L_{0}^{2}\right) /\left(L_{1} \cdot L_{2}+L_{0}^{2}\right)
$$

The value $L_{0}$ of the level of adaptation is most often equal to the average brightness of the current image [6], $L_{0}=\bar{L}$. The most wide practical application is characteristic for the definition of a weighted contrast of image elements [10, 11]:

$$
C^{\text {wei }}\left(L_{1}, L_{2}\right)=\left(L_{1}-L_{2}\right) /\left(L_{1}+L_{2}\right) \text {. }
$$

Another known definition of contrast is relative contrast, which is defined as [8]:

$$
\begin{gathered}
C^{r e l_{1}}\left(L_{1}, L_{2}\right)=\left(L_{1}-L_{2}\right) / \max \left(L_{1}, L_{2}\right), \\
C^{r e l_{2}}\left(L_{1}, L_{2}\right)=\left(L_{1}-L_{2}\right) /\left(1-\min \left(L_{1}, L_{2}\right)\right) .
\end{gathered}
$$

The main disadvantages of contrast definitions (1)-(4) are the uncertainty and the multiplicity of the conditions under which the extreme values of weighted contrast are achieved [8]. In [8] Vorobel (1999) has offered the linear definition of the absolute contrast of image elements which provides performance of the basic (discussed earlier) requirements to contrast:

$$
C^{V r b}\left(L_{1}, L_{2}\right)=\left(L_{1}-L_{2}\right) / L \mathrm{MAX}
$$

In [9] Vorobel and Berehulyak (2007) have proposed a generalized definition for absolute contrast (where $n>0$ ):

$$
C^{V B}\left(L_{1}, L_{2}\right)=\operatorname{sign}\left(L_{1}^{n}-L_{2}^{n}\right) \cdot\left|L_{1}^{n}-L_{2}^{n}\right|^{1 / n} .
$$

The linear definition of contrast, which satisfies the conditions of asymmetry and equivalence of impact of the arguments, of unambiguity and certainty of the conditions under which the equality to zero and the extreme values of contrast are achieved, and which is invariant to the linear transformations of the brightness scale, has the form:

$$
C^{Y}\left(L_{1}, L_{2}\right)=\left(L_{1}-L_{2}\right) /\left(L_{\max }-L_{\min }\right) \text {. }
$$

The definitions (1)-(7) of the contrast of image elements are called the contrast kernels [8] and are the basis for the construction of metrics of contrast for complex images.

The assessment of generalized contrast for complex (multi-element) images is usually carried out by measuring of contrast values of image elements (of objects and background) [6]. The various approaches to the measurement of the generalized contrast of complex image are known $[6,8]$. Currently, as a measure of generalized contrast of complex image most often used the averaged value of the contrast of image elements in relation to the preset value of adaptation level.

For example, in [6] Nesteruk (1970) proposed the definition of the generalized contrast for anisotropic images on the base of the weighted contrast $C^{N}(1)$ :

$$
C_{g e n}^{N}\left(L_{0}\right)=\int_{0}^{1}\left|\left(L^{2}-L_{0}^{2}\right) /\left(L^{2}+L_{0}^{2}\right)\right| \cdot p(L) d L .
$$

Currently, for the contrast measurement of image elements the definition of weighted contrast is most widely used, which has the form [8]:

$$
C_{\text {gen }}^{\text {wei }}\left(L_{0}\right)=\int_{0}^{1}\left|\left(L-L_{0}\right) /\left(L-L_{0}\right)\right| \cdot p(L) d L .
$$

However, contrast definitions (1)-(4) have significant disadvantages. Their main disadvantages are the uncertainty and the multiplicity of conditions of equality the extreme values.

To address the shortcomings specific to definitions (1) and (2) of weighted contrast, Vorobel (1999) has proposed the definition of generalized contrast on the base of the

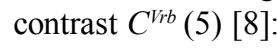

$$
\begin{gathered}
C_{\text {gen }}^{V}\left(L_{0}\right)=\frac{1}{2 L \mathrm{MAX}} \int_{0}^{1} \mid 2 \cdot\left(L-L_{0}\right)+L M A X- \\
-\left|2 \cdot\left(L-L_{0}\right)-L M A X\right| \mid \cdot p(L) d L .
\end{gathered}
$$

In [9] Vorobel and Berehulyak (2007) have proposed the generalized definition of the contrast for complex image:

$$
C_{g e n}^{V B}\left(L_{0}\right)=\frac{1}{2} \int_{0}^{L \mathrm{MAX}}\left|\sqrt[n]{2\left|\left(L^{n}-L_{0}^{n}\right)\right|}+1-\right| \sqrt[n]{2\left|\left(L^{n}-L_{0}^{n}\right)\right|}-1|| p(L) d L .
$$

The known definitions (8)-(11) are no-reference metrics for measurement of image contrast. The choice of concrete value of adaptation level $L_{0}$ for current image is a very difficult problem to the practical implementation of this approach to measurement of contrast and largely determines the accuracy of measuring of image contrast with the using (8)-(11).

\section{MATERIALS AND METHODS}

In this paper the no-reference method of assessment of generalized contrast of complex image by finding the mean of all values of generalized contrast for all possible values $L_{0}$ of the level of adaptation for the current image is proposed.

As an assessment of the generalized contrast we propose the using of the average value from all possible values of 
generalized contrast which correspond to all possible values of the level of adaptation for the current image:

$$
C_{\text {age }}=\int_{L_{\min }}^{L_{\max }} C_{0}\left(L_{i}\right) \cdot p\left(L_{i}\right) d L_{i} .
$$

In this case we propose to define the generalized contrast of complex image at a given value of a level of adaptation as:

$$
\begin{gathered}
C_{0}\left(L_{0}\right)=\int_{0}^{1}\left|C\left(L_{j}, L_{0}\right)\right| \cdot p\left(L_{j}, L_{0}\right) / p\left(L_{0}\right) d L_{j}, \\
L_{0} \in\left[L_{\min }, L_{\max }\right], \\
p\left(L_{0}\right)=\int_{0}^{1} p\left(L_{j}, L_{0}\right) d L_{j} .
\end{gathered}
$$

The proposed method of no-reference assessment of generalized contrast of complex image is defined in accordance with (12) and (13). The expressions (12), (13) define the metric for the contrast measurement of multielement images with using various known definitions of contrast kernels.

It should be noted that the two-dimensional distribution $p\left(L_{j}, L_{0}\right)$ of brightness values on the current image is overwhelmingly not known.

In the case where the objects on image are the equally important and independent and have no influence on each other (are independent events of relative to each other), we have:

$$
p\left(L_{j}, L_{0}\right)=p\left(L_{j}\right) \cdot p\left(L_{0}\right) .
$$

In this case for (13), (12) using (15) we obtain:

$$
\begin{gathered}
C_{0}\left(L_{0}\right)=\int_{0}^{1}\left|C\left(L_{j}, L_{0}\right)\right| \cdot p\left(L_{j}\right) d L_{j}, \\
C_{\text {ave }}=\int_{L_{\min }}^{L_{\max }} \int_{0}^{1}\left|C\left(L_{j}, L_{0}\right)\right| \cdot p\left(L_{j}\right) \cdot p\left(L_{0}\right) d L_{j} d L_{0} .
\end{gathered}
$$

The proposed method (12), (13), (16) provides the opportunity of creating the contrast metrics with using the various known definitions (1)-(7) of contrast of image elements (of contrast kernels). Accordingly, the histogrambased metrics of contrast on the basis of the definitions (12), (16) using known definitions (1), (2), (5)-(7) of contrast kernels can be defined as follows:

$$
\begin{gathered}
C_{\text {ave }}^{N}=\int_{0}^{1} \int_{0}^{1}\left|\left(L_{i} \cdot L_{j}-\bar{L}^{2}\right) /\left(L_{i} \cdot L_{j}+\bar{L}^{2}\right)\right| \cdot p\left(L_{i}\right) \cdot p\left(L_{j}\right) d L_{i} d L_{j}, \\
C_{\text {ave }}^{\text {wei }}=\int_{0}^{1} \int_{0}^{1}\left|\left(L_{i}-L_{j}\right) /\left(L_{i}+L_{j}\right)\right| \cdot p\left(L_{i}\right) \cdot p\left(L_{j}\right) d L_{i} d L_{j}, \\
C_{\text {ave }}^{V}=\int_{0}^{1} \int_{0}^{1} \frac{\left|L_{i}-L_{j}\right|}{L \mathrm{MAX}} \cdot p\left(L_{i}\right) \cdot p\left(L_{j}\right) d L_{i} d L_{j},
\end{gathered}
$$

$$
\begin{gathered}
C_{\text {ave }}^{V B}=\int_{0}^{1} \int_{0}^{1}\left|L_{i}^{n}-L_{j}^{n}\right|^{1 / n} \cdot p\left(L_{i}\right) \cdot p\left(L_{j}\right) d L_{i} d L_{j}, \\
C_{\text {ave }}^{Y}=\int_{0}^{1} \int_{0}^{1}\left|\frac{L_{i}-L_{j}}{L_{\max }-L_{\min }}\right| \cdot p\left(L_{i}\right) \cdot p\left(L_{j}\right) d L_{i} d L_{j} .
\end{gathered}
$$

The known (8)-(11) and the proposed (18)-(22) definitions are no-reference contrast metric for quantitative assessment of generalized contrast of complex images. A comparison of the proposed and known histogram-based methods of contrast assessment for complex images was carried out in Sections 4, 5 and 6.

\section{EXPERIMENTS}

Known (8)-(11) and proposed (18)-(22) metrics of contrast were programmed in the interactive environment of programming MATLAB to carry out a subsequent comparative analysis of their effectiveness. A comparison of the known (8)-(11) and proposed (18)-(22) methods were carried out on the basis of measurement of generalized contrast for the two groups of test images. The first group consists of fifteen test images, which are the results of linear stretching of a well-known initial image (Fig. 1) for the ranges $[0,00-$ $0,40],[0,15-0,55],[0,300,70],[0,450,85],[0,60-1,00],[0,00-$ $0,60],[0,10-0,70],[0,20-0,80],[0,30-0,90],[0,40-1,00],[0,00-$ $0,85],[0,05-0,90],[0,10-0,95],[0,15-1,00],[0,00-1,00]$ (Fig. 2). The second group of the test images consists of fifteen reference images with complex structural nature (Fig. 3).

The results of measurements of generalized contrast for the two groups of test images (Fig. 2 and Fig. 3) with the use of known (8)-(11) and proposed (18)-(22) metrics are shown in Section 5.

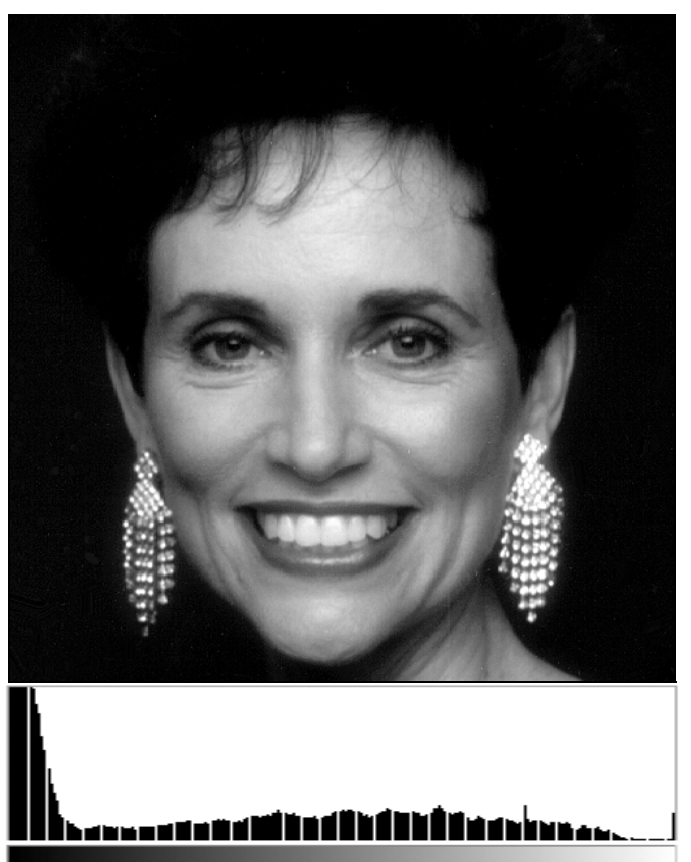

Figure 1 - Initial test image and its histogram 


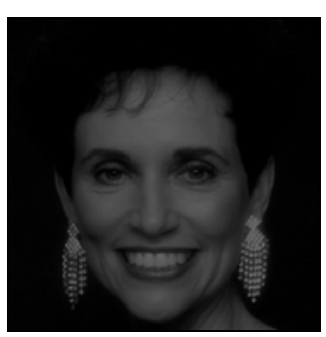

a

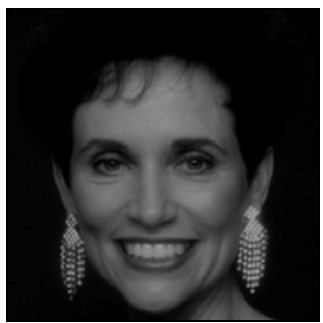

f

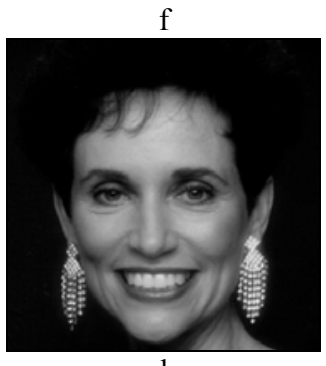

$\mathrm{k}$

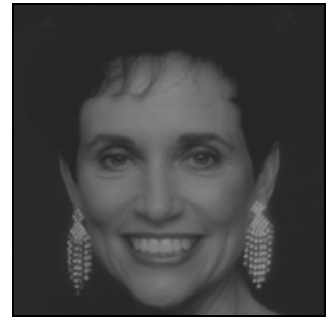

b
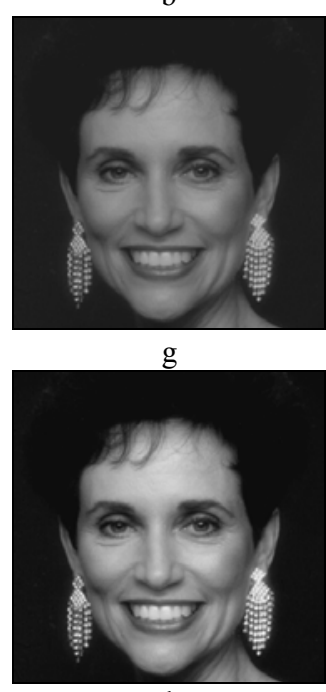

1
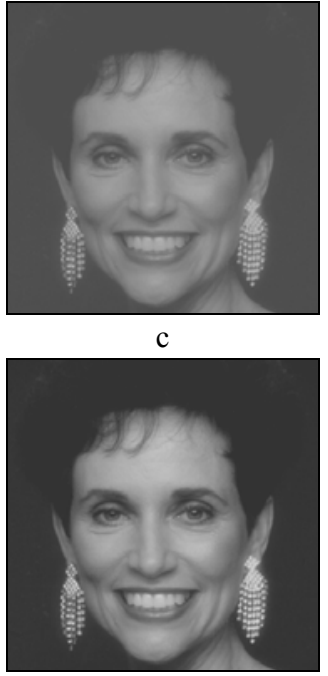

h

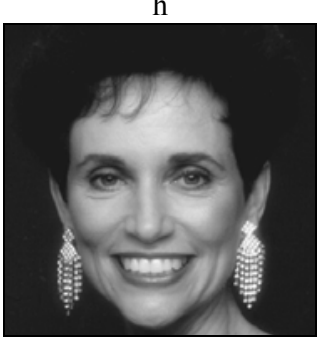

m

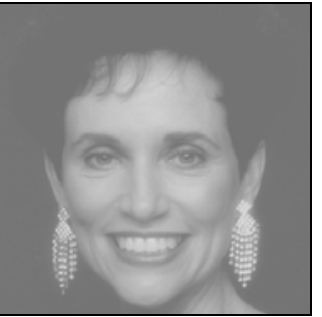

d
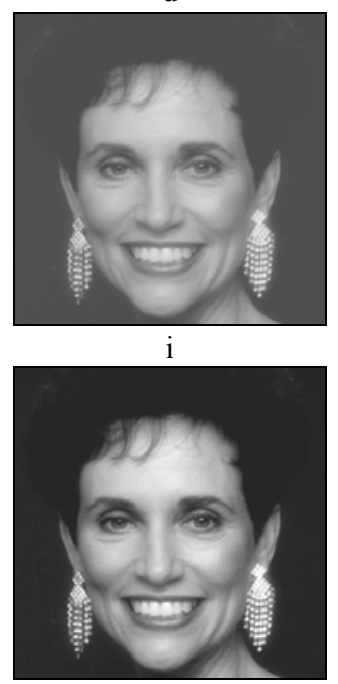

n

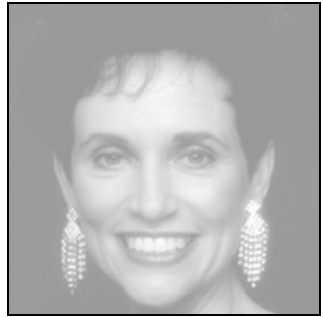

e
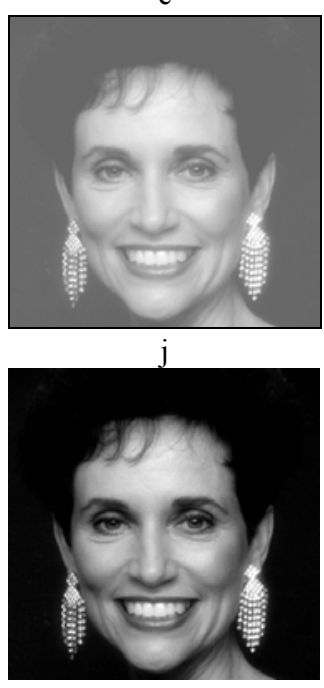

o

Figure 2 - The appearance of test images of the first group with the dynamic range:

$\mathrm{a}-[0,00-0,40] ; \mathrm{b}-[0,15-0,45] ; \mathrm{c}-[0,30-0,70] ; \mathrm{d}-[0,45-0,85] ; \mathrm{e}-[0,60-1,00] ;$

$\mathrm{f}-[0,00-0,60] ; \mathrm{g}-[0,10-0,70] ; \mathrm{h}-[0,20-0,80] ; \mathrm{i}-[0,30-0,90] ; \mathrm{j}-[0,40-1,00]$

$\mathrm{k}-[0,00-0,85] ; 1-[0,05-0,90] ; \mathrm{m}-[0,10-0,95] ; \mathrm{n}-[0,15-1,00] ; \mathrm{o}-[0,00-1,00]$

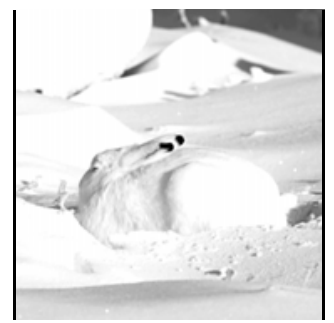

$\mathrm{a}$

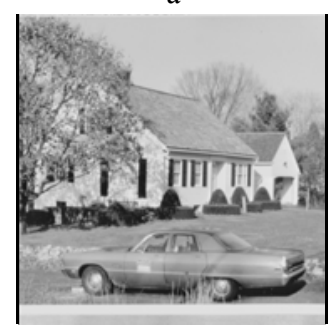

f

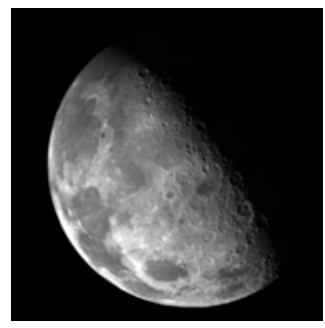

$\mathrm{k}$

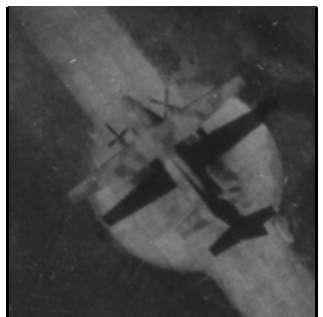

b

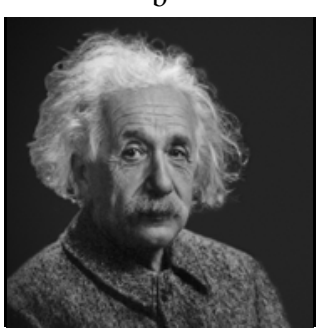

$\mathrm{g}$

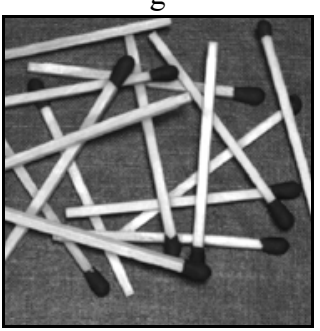

1

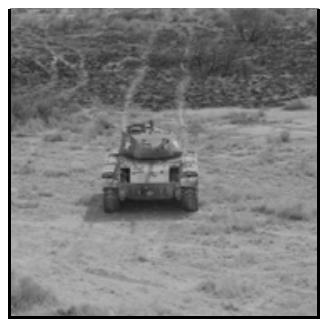

c

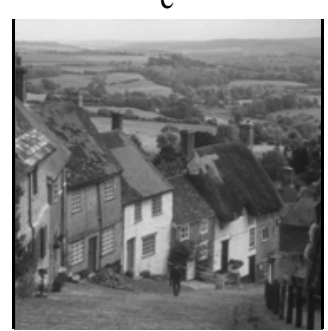

$\mathrm{h}$

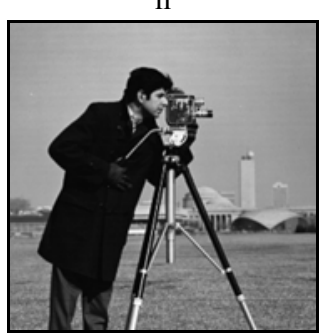

$\mathrm{m}$

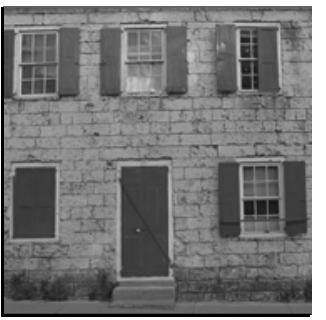$$
\text { d }
$$
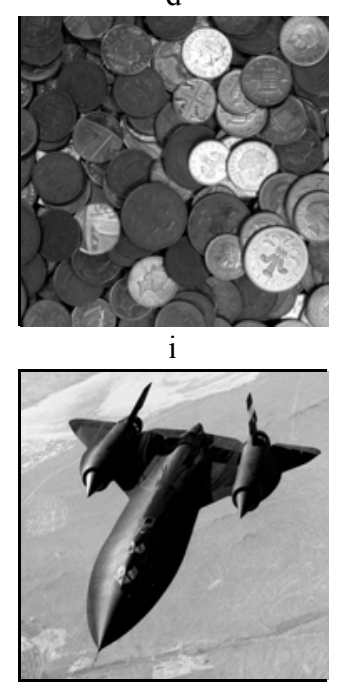

n

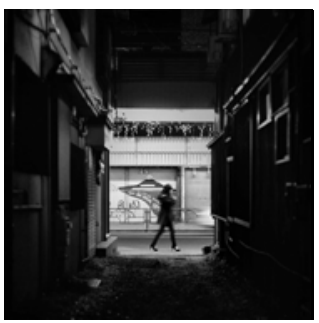

e
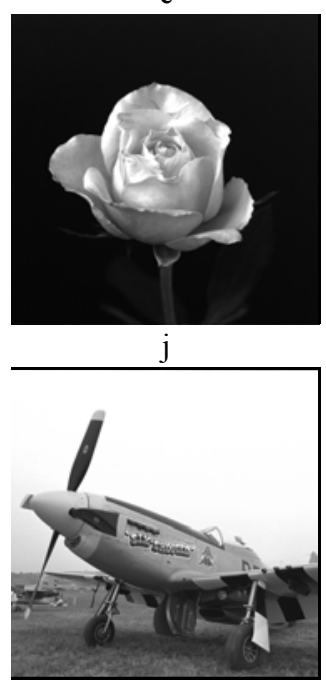

Figure 3 -Test images of the second group 


\section{RESULTS}

Researches of the effectiveness of the proposed (8)(11) and known (18)-(22) no-reference metrics of contrast were carried out by measuring (by quantitative assessment of the value) of the generalized contrast for two groups of test images with complex structure.

The results of the measurement for the first and the second groups of test images are shown in Table 1 and Table 2. Graphs of the values (Tab. 1) of generalized contrast for test images of the first group (Fig. 2) are shown in Fig. 4. Graphs of the values (Tab. 2) of generalized contrast for test images of the second group (Fig. 3) are shown in Fig. 5.

\section{DISCUSSION}

The results of the measurements show that the definitions (8), (9) and (18), (19) of the weighted contrast using contrast kernels (1), (2) are invariant to linear stretching of brightness range, but their values are significantly changed at additive transformations of brightness values on image (of mean value of brightness on image) (Fig. 4). The assessments (10), (20) on the basis of absolute kernel of Vorobel (5) of absolute contrast are invariant to additive transformations and are proportional to multiplicative transformations of image brightness scale (Fig. 4). The assessments (11), (21) on the basis of non-linear absolute kernel of Vorobel and Berehulyak (6) are changed substantially under linear transformations of the image brightness (Fig. 4). The contrast assessment (22) on the basis of linear kernel (7) is invariant to linear transformations of image brightness scale (Fig. 4). The assessments of averaged contrast (20) and (22) for absolute kernel of Vorobel (5) and of linear kernel (7) coincide when analyzing prenormalized images (Fig. 4). The values of known assessments of the generalized contrast (10), (11) on the basis of contrast kernel of Vorobel (5) and contrast kernel of Vorobel and Berehulyak (6) are proportional the proposed assessments (20), (21) of averaged contrast, however known definitions (10), (11) of the generalized contrast give the significantly overstated values of contrast assessments (Fig. 4 and Fig. 5). The assessments (20) and (22) used absolute kernel of Vorobel (5) and linear kernel (7) are the closest and are most suitable for quantitative assessment of contrast of images with complex structure (Fig. 5).

Table 1 - Results of calculating for the first group of test images

\begin{tabular}{|l|c|c|c|c|c|c|c|c|c|c|c|c|c|c|c|}
\hline & $2 . \mathrm{a}$ & $2 . \mathrm{b}$ & $2 . \mathrm{c}$ & $2 . \mathrm{d}$ & $2 . \mathrm{e}$ & $2 . \mathrm{f}$ & $2 . \mathrm{g}$ & $2 . \mathrm{h}$ & $2 . \mathrm{i}$ & $2 . \mathrm{j}$ & $2 . \mathrm{k}$ & 2.1 & $2 . \mathrm{m}$ & $2 . \mathrm{n}$ & 2.0 \\
\hline$L_{\min }$ & 0.00 & 0.15 & 0.30 & 0.45 & 0.60 & 0.00 & 0.10 & 0.20 & 0.30 & 0.40 & 0.00 & 0.05 & 0.10 & 0.15 & 0.00 \\
\hline$L_{\max }$ & 0.40 & 0.45 & 0.70 & 0.85 & 1.00 & 0.60 & 0.70 & 0.80 & 0.90 & 1.00 & 0.85 & 0.90 & 0.95 & 1.00 & 1.00 \\
\hline$C_{\text {gen }}^{N}$ & 0.802 & 0.392 & 0.247 & 0.182 & 0.144 & 0.802 & 0.567 & 0.417 & 0.327 & 0.270 & 0.802 & 0.721 & 0.631 & 0.558 & 0.802 \\
\hline$C_{\text {gen }}^{\text {wei }}$ & 0.647 & 0.207 & 0.126 & 0.092 & 0.073 & 0.646 & 0.321 & 0.222 & 0.170 & 0.139 & 0.646 & 0.471 & 0.374 & 0.315 & 0.646 \\
\hline$C_{\text {gen }}^{V}$ & 0.207 & 0.207 & 0.206 & 0.206 & 0.207 & 0.310 & 0.309 & 0.310 & 0.310 & 0.310 & 0.436 & 0.436 & 0.435 & 0.437 & 0.504 \\
\hline$C_{\text {gen }}^{V B}$ & 0.205 & 0.252 & 0.276 & 0.295 & 0.310 & 0.307 & 0.347 & 0.373 & 0.392 & 0.408 & 0.431 & 0.456 & 0.474 & 0.489 & 0.496 \\
\hline$C_{\text {ave }}^{N}$ & 0.813 & 0.251 & 0.158 & 0.117 & 0.093 & 0.810 & 0.379 & 0.267 & 0.209 & 0.173 & 0.810 & 0.562 & 0.442 & 0.372 & 0.813 \\
\hline$C_{\text {ave }}^{\text {wei }}$ & 0.688 & 0.224 & 0.142 & 0.105 & 0.084 & 0.697 & 0.325 & 0.237 & 0.186 & 0.155 & 0.696 & 0.450 & 0.370 & 0.322 & 0.688 \\
\hline$C_{\text {ave }}^{V}$ & 0.123 & 0.123 & 0.122 & 0.122 & 0.123 & 0.184 & 0.183 & 0.184 & 0.183 & 0.184 & 0.261 & 0.260 & 0.260 & 0.261 & 0.307 \\
\hline$C_{\text {ave }}^{V B}$ & 0.131 & 0.159 & 0.172 & 0.184 & 0.193 & 0.196 & 0.219 & 0.235 & 0.246 & 0.256 & 0.278 & 0.293 & 0.303 & 0.314 & 0.327 \\
\hline$C_{\text {ave }}^{Y}$ & 0.307 & 0.307 & 0.305 & 0.306 & 0.307 & 0.307 & 0.306 & 0.307 & 0.306 & 0.307 & 0.306 & 0.306 & 0.307 & 0.307 & 0.307 \\
\hline
\end{tabular}

Table 2 - Results of calculating for the second group of test images

\begin{tabular}{|l|c|c|c|c|c|c|c|c|c|c|c|c|c|c|c|}
\hline & $3 . \mathrm{a}$ & $3 . \mathrm{b}$ & $3 . \mathrm{c}$ & $3 . \mathrm{d}$ & $3 . \mathrm{e}$ & $3 . \mathrm{f}$ & $3 . \mathrm{g}$ & $3 . \mathrm{h}$ & $3 . \mathrm{i}$ & $3 . \mathrm{j}$ & $3 . \mathrm{k}$ & 3.1 & $3 . \mathrm{m}$ & $3 . \mathrm{n}$ & $3 . \mathrm{o}$ \\
\hline$C_{\text {gen }}^{N}$ & 0.122 & 0.348 & 0.250 & 0.297 & 0.780 & 0.232 & 0.532 & 0.325 & 0.408 & 0.820 & 0.857 & 0.412 & 0.422 & 0.363 & 0.463 \\
\hline$C_{\text {gen }}^{\text {wei }}$ & 0.065 & 0.184 & 0.132 & 0.159 & 0.563 & 0.128 & 0.306 & 0.178 & 0.236 & 0.552 & 0.745 & 0.231 & 0.281 & 0.259 & 0.270 \\
\hline$C_{\text {gen }}^{V}$ & 0.208 & 0.196 & 0.243 & 0.262 & 0.303 & 0.289 & 0.328 & 0.304 & 0.336 & 0.375 & 0.455 & 0.393 & 0.410 & 0.441 & 0.640 \\
\hline$C_{\text {gen }}^{V B}$ & 0.301 & 0.242 & 0.322 & 0.333 & 0.304 & 0.378 & 0.367 & 0.370 & 0.387 & 0.380 & 0.439 & 0.454 & 0.468 & 0.508 & 0.746 \\
\hline$C_{\text {ave }}^{N}$ & 0.102 & 0.238 & 0.186 & 0.220 & 0.678 & 0.194 & 0.386 & 0.253 & 0.329 & 0.623 & 0.920 & 0.318 & 0.441 & 0.432 & 0.366 \\
\hline$C_{\text {ave }}^{\text {wei }}$ & 0.092 & 0.229 & 0.176 & 0.213 & 0.537 & 0.184 & 0.345 & 0.246 & 0.311 & 0.434 & 0.618 & 0.292 & 0.368 & 0.358 & 0.321 \\
\hline$C_{\text {ave }}^{V}$ & 0.142 & 0.126 & 0.159 & 0.175 & 0.198 & 0.201 & 0.209 & 0.215 & 0.235 & 0.228 & 0.265 & 0.264 & 0.263 & 0.281 & 0.370 \\
\hline$C_{\text {ave }}^{\text {VB }}$ & 0.218 & 0.168 & 0.224 & 0.237 & 0.214 & 0.280 & 0.251 & 0.283 & 0.292 & 0.247 & 0.277 & 0.331 & 0.315 & 0.333 & 0.446 \\
\hline$C_{\text {ave }}^{Y}$ & 0.142 & 0.170 & 0.176 & 0.195 & 0.198 & 0.237 & 0.213 & 0.244 & 0.235 & 0.228 & 0.266 & 0.276 & 0.263 & 0.281 & 0.370 \\
\hline
\end{tabular}




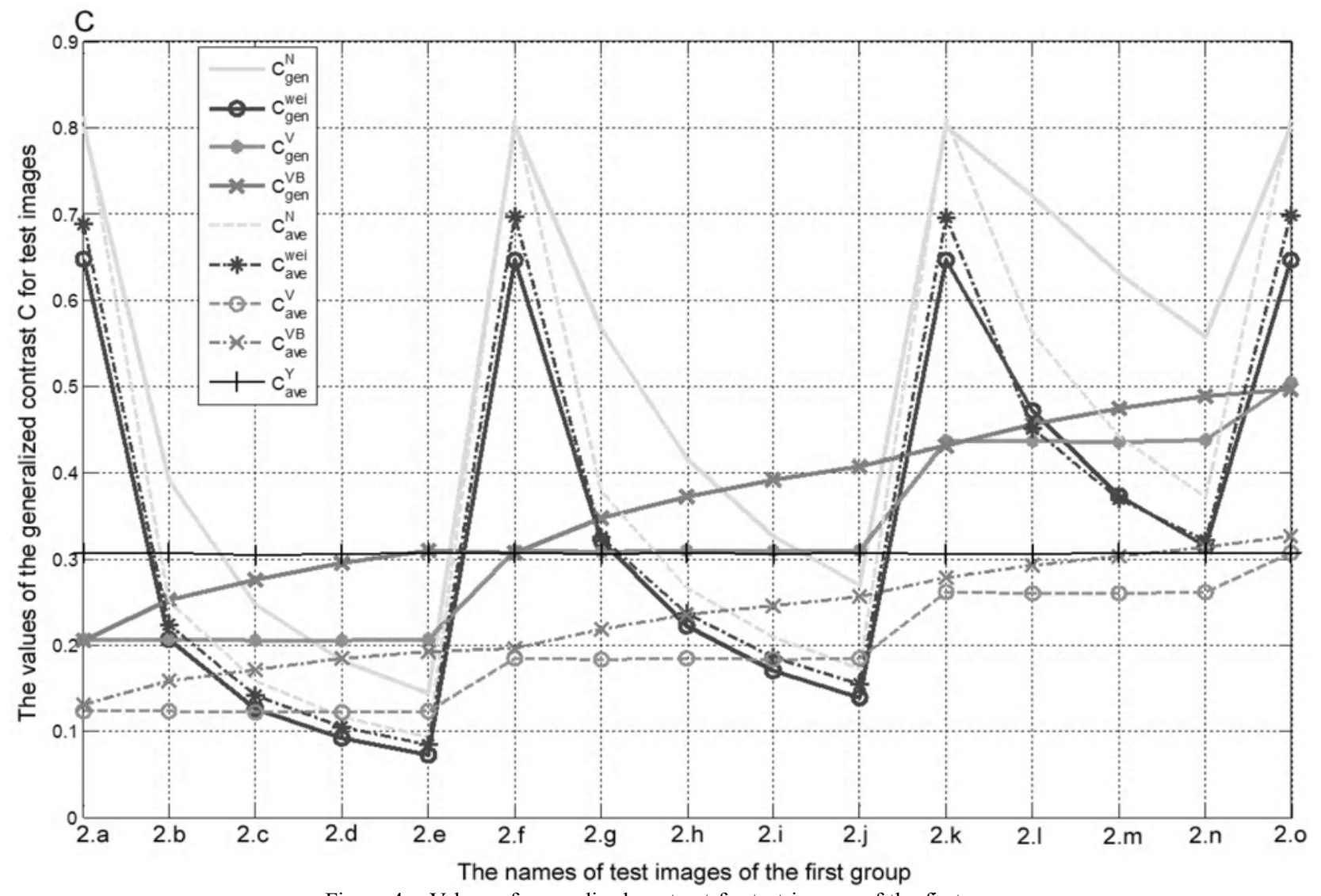

Figure 4 - Values of generalized contrast for test images of the first group

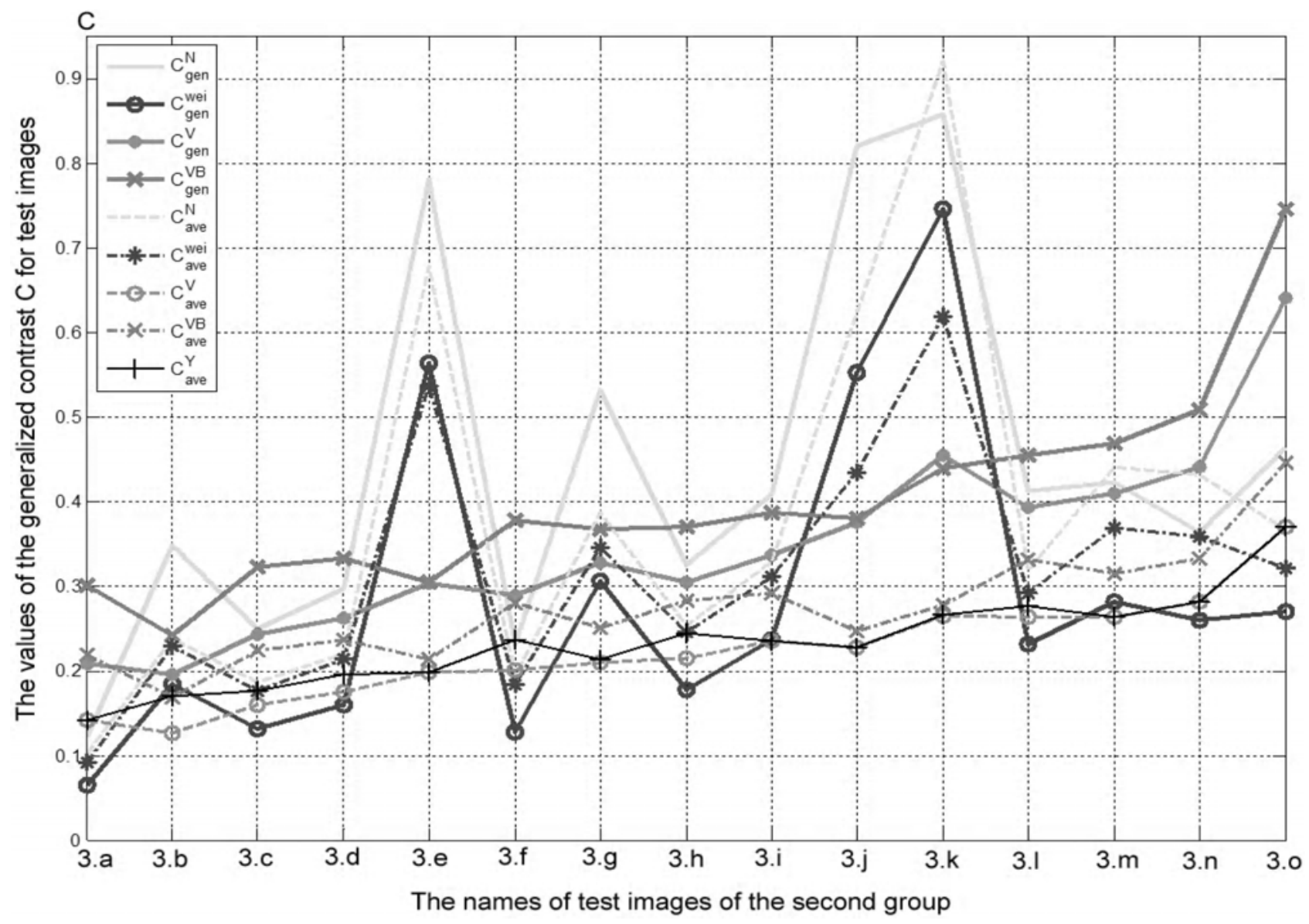

Figure 5 - Values of generalized contrast for test images of the second group 


\section{CONCLUSIONS}

The problem of no-reference measuring of a generalized contrast of complex images is considered. The urgent problem of increasing the accuracy and reliability of noreference measurements of contrast for multi-element images with complex structure is solved to improve the accuracy of the image quality assessment in automatic mode.

The histogram-based method of no-reference contrast measurement of multi-element image with complex structure by finding the mean of all values of generalized contrast for all possible values of the level of adaptation for the current image is firstly proposed. The no-reference contrast metrics on the basis of the averaged value of contrast for all pairs of image elements (objects and background) using various definitions of contrast of image elements (contrast kernels) is firstly proposed. This allows to increase the accuracy of measuring of generalized contrast for multi-element images with complex structure and, as a consequence, to improve exactness and reliability of image quality assessment for complex images. This also allows to provide the operative measurement of contrast and the assessment of image quality in the automatic mode with the level of computing costs which is acceptable to processing and image analysis in real time. The practical significance of obtained results is that software implementation of the proposed contrast metrics is developed, as well as experiments to study their properties at various definitions of contrast kernels are carried out.

The experimental results allow to recommend the proposed method of no-reference measurement of contrast to use in practice for image quality assessment in automatic mode as well as to ensure the effective choice of the definitions of contrast of image elements (of contrast kernels) and conditions of their use for various practical applications.

\section{ACKNOWLEDGEMENTS}

The work was carried out within the framework of the project of Special design office of television systems (Lviv,
Ukraine) "On-board system of enhanced vision for transport vehicles" (No. 118/16).

\section{REFERENCES}

1. Wang Z. Image quality assessment: From error visibility to structural similarity / Z. Wang, A. C. Bovik, H. R. Sheikh, E. P. Simoncelli // IEEE Transactions on Image Processing. - 2004. - Vol. 13, № 4. - P. 600-612. DOI: 10.1109/TIP.2003.819861.

2. Wang Z. Why is image quality assessment so difficult? / Z. Wang, A. C. Bovik, L. Lu // IEEE International Conference on Acoustics, Speech and Signal Processing, Orlando, FL, USA, May 2002.Vol. 4. - P. 3313-3316. DOI: 10.1109/ICASSP.2002.1004620.

3. Wang Z. A universal image quality index / Z. Wang and A. Bovik // Signal Processing Letters. - 2002. - Vol. 9, № 3. - P. 81-84. DOI: $10.1109 / 97.995823$.

4. Wang Z. Modern Image Quality Assessment / Z. Wang, A.C. Bovik. - San Rafael, CA, USA: Morgan \& Claypool, 2006. 160 p. DOI: $10.2200 /$ S00010ED1 V01Y200508IVM003.

5. No-reference image and video quality assessment: a classification and review of recent approaches / [M. Shahid, A. Rossholm, B. LÖvström, H.-J. Zepernick] // EURASIP Journal on Image and Video Processing. - 2014. - № 1. - P. 1-32. DOI: 10.1186/ 1687-5281-2014-40.

6. Нестерук В. Ф. Контрастный закон восприятия света / В.Ф. Нестерук, Н. Н. Порфирьева // Оптика и спектроскопия. 1970. - Т. ХХІХ, вып. 6. - С. 1138-1143.

7. Peli E. Contrast in Complex Images / E. Peli // Journal of the Optical Society of America A. - October 1990. - Vol. 7, №10. P. 2032-2040. DOI: 10.1364/JOSAA.7.002032.

8. Воробель Р. Логарифмічна обробка зображень / Р. Воробель. Київ, Наукова думка, 2012. - 231 с.

9. Vorobel R. Image contrast and its connection with fuzzy logic / R. Vorobel, O. Berehulyak // Proceedings of II International Workshop on Inductive Modeling (IWIM), Prague, Czech Republic, 2007. - P. 104-110. ISBN 978-80-01-03881-9.

10.Gonzalez R. C. Digital Image Processing, 2nd Edition / R. C. Gonzalez, R. E. Woods. - NY: Prentice Hall, 2002. - 976 p. ISBN 13: 978-0201180756, ISBN10: 0201180758.

11. Pratt W. K. Digital Image Processing / William K. Pratt. - New York, Chichester : John Wiley \& Sons, second edition, 1993. 720 p. DOI: $10.1002 / 0471221325$.

Article was submitted 16.04.2017. After revision 25.05.2017.

Єлманова О. С. ${ }^{1}$, Романишин Ю. М. ${ }^{2}$

${ }^{1}$ Аспірант, Національний університет «Львівська політехніка», Львів, Україна

2Д-р техн. наук, завідувач кафедри електронних засобів інформаційно-комп’ютерних технологій, Національний університет «Львівська політехніка», Львів, Україна, професор кафедри, Варміньско-Мазурський університет в Ольштині, Ольштин, Польща

\section{КІЛЬКІСНА ОЦІККА БЕЗ ЕТАЛОНУ ДЛЯ УЗАГАЛЬНЕНОГО КОНТРАСТУ СКЛАДНИХ ЗОБРАЖЕНЬ}

Актуальність. В наш час вимірювання (кількісна оцінка) якості зображень у автоматичному режимі $є$ надзвичайно актуальною проблемою для більшості практичних застосувань. Вимірювання якості зображення без еталону є одним із найбільш актуальних і складних завдань обробки та аналізу зображень. Контраст є найбільш важливою кількісною характеристикою, яка визначає об'єктивну якість зображення в цілому. В наш час розробка нових ефективних методів (метрик) для вимірювання узагальненого контрасту зображень у автоматичному режимі $є$ однією $є$ найбільш актуальних задач обробки і аналізу зображень.

Мета. Розробка методу вимірювання узагальненого контрасту багатоелементних зображень зі складною структурою за їх гістограмою на основі усередненого контрасту елементів зображення (об'єктів і фону) з використанням різних визначень ядра контрасту.

Метод. Аналіз відомих підходів до вимірювання локального контрасту елементів зображення, відомих методів кількісної оцінки узагальненого контрасту складних зображень, а також результатів експериментальних досліджень для ряду складних реальних і тестових зображень дозволив виявити властиві їм закономірності (відповідність основним вимогам до визначення контрасту, характер і динаміку змін контрасту при лінійних перетвореннях шкали яскравості зображення), які проявляються в залежності від використання різних визначень ядер контрасту і метрик узагальненого контрасту зображень.

Результати. Запропоновано новий метод вимірювання узагальненого контрасту без еталону для складних зображень на основі гістограми. Запропоновано метрику вимірювання узагальненого контрасту для складних зображень на основі усередненого контрасту для всіх окремих пар елементів зображення (об'єктів і фону) для різних визначень ядра контрасту.

Висновки. Запропонована нова метрика контрасту на основі середнього для всіх значень контрасту всіх елементів зображення дозволяє забезпечити точну кількісну оцінку узагальненого контрасту складних реальних зображень і оцінити (прогнозувати) якість сприйняття зображення при проведенні суб’єктивних (якісних) експертних оцінок. 
Ключові слова: обробка зображень, оцінка якості зображення, вимірювання контрасту, метрика без еталону, узагальнений контраст, складне зображення, гістограма.

Елманова Е. С. ${ }^{1}$, Романишин Ю. М. ${ }^{2}$

${ }^{1}$ Аспирант, Национальный университет «Львовская политехника», Львов, Украина

${ }^{2}$ Д-р техн. наук, заведующий кафедры электронных средств информационно-компьютерных технологий, Национальный универси-

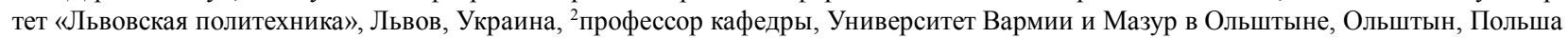

КОЛИЧЕСТВЕННАЯ ОЦЕНКА БЕЗ ЭТАЛОНА ДЛЯ ОБОБЩЕННОГО КОНТРАСТА СЛОЖНЫХ ИЗОБРАЖЕНИЙ

Актуальность. В настоящее время измерение (количественная оценка) качества изображений в автоматическом режиме является чрезвычайно актуальной задачей для большинства практических приложений. Измерение качества изображения без эталона является одной из наиболее актуальных и сложных задач обработки и анализа изображений. Контраст является наиболее важной количественной характеристикой, которая определяет объективное качество изображения в целом. В настоящее время одной из наиболее актуальных задач анализа изображений является разработка новых эффективных методов (метрик) для измерения обобщенного контраста изображений в автоматическом режиме.

Цель. Разработка метода измерения обобщенного контраста многоэлементных изображений со сложной структурой по их гистограмме на основе измерения среднего значения контраста всех элементов изображения для различных определений ядра контраста.

Метод. Анализ известных подходов к измерению контраста элементов изображения и известных методов количественной оценки обобщенного контраста сложных изображений, а также результатов экспериментальных исследований для ряда сложных реальных и тестовых изображений позволил выявить существующие закономерности (соответствие требованиям к определению контраста, характер изменений контраста при линейных преобразованиях шкалы яркости), которые проявляются в зависимости от использования различных определений ядер контраста и метрик обобщенного контраста изображений.

Результаты. Предложен новый метод измерения обобщенного контраста без эталона для сложных изображений. Предложена метрика измерения обобщенного контраста сложных изображений по их гистограмме на основе усредненного контраста для всех отдельных пар элементов изображения для различных определений ядра контраста.

Выводы. Предложенная новая метрика контраста позволяет обеспечить точную количественную оценку обобщенного контраста сложных реальных изображений и оценить воспринимаемое качество изображений при проведении субъективных экспертных оценок.

Ключевые слова: обработка изображений, оценка качества изображения, измерение контраста, метрика без эталона, обобщенный контраст, сложное изображение, гистограмма.

\section{REFERENCES}

1. Wang Z., Bovik A. C., Sheikh H. R., Simoncelli E. P. Image quality assessment: From error visibility to structural similarity, IEEE Transactions on Image Processing, 2004, Vol. 13, No. 4, pp. 600-612. DOI: 10.1109/TIP.2003.819861.

2. Wang Z., Bovik A. C., Lu L. Why is image quality assessment so difficult?, IEEE International Conference on Acoustics, Speech and Signal Processing, Orlando, FL, USA, May 2002, Vol. 4, pp. 3313-3316. DOI: 10.1109/ICASSP.2002.1004620.

3. Wang Z., Bovik A. A universal image quality index, Signal Processing Letters, 2002, Vol. 9, No. 3, pp. 81-84. DOI: 10.1109/ 97.995823 .

4. Wang Z., Bovik A. C. Modern Image Quality Assessment. San Rafael, CA, USA, Morgan \& Claypool, 2006, 160 p. DOI: 10.2200/S00010ED1 V01Y200508IVM003.

5. Shahid M., Rossholm A., Lö vström B., Zepernick H.-J. Noreference image and video quality assessment: a classification and review of recent approaches, EURASIP Journal on Image and
Video Processing, 2014, No. 1, pp. 1-32. DOI: 10.1186/16875281-2014-40.

6. Nesteruk V. F., Porfireva N. N. Kontrastnyiy zakon vospriyatiya sveta, Optika i spektroskopiya, 1970, Vol. XXIX, vyp. 6, pp. 1138-1143.

7. Peli E. Contrast in Complex Images, Journal of the Optical Society of America A, October 1990, Vol. 7, No. 10, pp. 20322040. DOI: $10.1364 /$ JOSAA.7.002032.

8. Vorobel' R. Logaryfmichna obrobka zobrazhen'. Kiev, Naukova dumka, 2012, $231 \mathrm{p}$.

9. Vorobel R., Berehulyak O. Image contrast and its connection with fuzzy logic, Proceedings of II International Workshop on Inductive Modeling (IWIM), Prague, Czech Republic, 2007, pp. 104-110. ISBN 978-80-01-03881-9.

10. Gonzalez R. C., Woods R. E. Digital Image Processing, 2nd Edition. NY, Prentice Hall, 2002, 976 p. ISBN13: 978-0201180756, ISBN10: 0201180758.

11. Pratt W.K. Digital Image Processing. New York, Chichester, John Wiley \& Sons, second edition, 1993, 720 p. DOI: 10.1002/ 0471221325 . 